\title{
ANALISIS DETERMINAN \\ PERUBAHAN PENAWARAN BARANG EKSPOR INDONESIA
}

\section{Sarwedi}

\begin{abstract}
This study analyzes the effects of structural economic movement on the change of indonesia's exports and examines the validity of the ignacy theory concerning structural economic movement in relation to the changes of of export composition. The study utilize an ordinary mechanism of WLS, namely the Wald model,

The estimation resulted through the combination of ECM and WLS shows that the price of export goods/merchandises has a positive effect and is significant in the short-term. Yet, over the long-term period, the increase in export commodity price causes the decrease in export volumes. Meanwhile, the relationship between export volume and inflation is not significant, either in the short-term or long-term. Foreign exchange interestingly has a positive and significant relationship with the export volume over a short-term period, but in the long-term it has a reverse effect, that is, it decreases export volume. Foreign investment has a positive and significant relationship with export volume in the long-term, the significance, however, weakens over the short-term period.

The structural economic movement has a positive and significant relationship over a short-term period with export volume, but over long-term period the relationship is not statistically strong. Thus, the structural economic movement towards more on the growth of industry sector could stimulate the growth in export aggregately. This evidence provides further support on the Ignacy theory (1980) if it is applied on Indonesian international economy, especially for the period of 1983-1997.
\end{abstract}

JEL Classification: C32, F14, O24

Keyword: Weighted Least Square, Error Correction Model, Structural Economic Movement, Export Change

1 Guru besar Fakultas Ekonomi Universitas Jember dan Ketua ISEI Pengurus Cabang Jember; sebelumnya adalah dekan FE Unej; dekan@fe.unej.ac.id. 


\section{PENDAHULUAN}

Hampir setiap negara berkembang dewasa ini telah menjadikan pembangunan sebagai komitmen bangsa untuk mengejar ketertinggalannya dalam berbagai aspek kehidupan. Salah satu aspeknya adalah pembangunan ekonomi yang merupakan bagian integral dari pembangunan nasional suatu negara. Pembangunan ekonomi adalah suatu proses yang menyebabkan pendapatan per kapita penduduk meningkat dalam jangka panjang yang dapat mendorong perbaikan kesejahteraan ekonomi masyarakat miskin. Untuk mewujudkan pembangunan ekonomi tersebut, Indonesia melakukan pembangunan di segala sektor ekonomi. Salah satu sektor ekonomi yang mendapat perhatian adalah sektor perdagangan yang membawa konsekuensi pada keterbukaan ekonomi domestik terhadap perkonomian internasional.

Menurut pandangan kaum klasik dan neo-klasik, alasan utama terjadinya perdagangan internasional adalah terciptanya keuntungan bagi kedua negara yang melakukan perdagangan. Perdagangan suatu negara dengan negara lainnya terjadi tidak lain karena kedua negara tersebut mengharapkan untuk saling memperoleh keuntungan berupa peningkatan efisiensi produksi. Oleh karena itu dengan melakukan perdagangan, suatu negara dapat membeli dengan harga yang lebih rendah dibandingkan apabila memproduksi sendiri dan mungkin dapat menjual ke luar negeri pada tingkat harga yang relatif tinggi.

Perdagangan internasional yang dilakukan oleh suatu negara juga berkaitan dengan corak pergeseran struktur ekonominya. Sedangkan corak pergeseran struktur ekonomi ditentukan oleh perubahan komposisi produksi (primary oriented), sektor industri (industry oriented), atau keseimbangan kedua sektor tersebut. Corak pergeseran struktur ekonomi juga ditentukan oleh perbedaan faktor timing dimana pergeseran strukturekonomi berlangsung. Dengan demikian, terlihat adanya hubungan yang relatif erat antara pergeseran struktur ekonomi dengan corak perdagangan suatu negara.

Beberapa studi empiris yang berkaitan dengan ekspor adalah: The Supply and Demand for Exports: A Simultaneous Approach (Goldstein dan Khan, 1979: 278-286), Export Demand and Supply for Group of Non Oil Developing Countries (Bond, 1985: 56-77), An Econometric Study of Primary Commodity Exports from Developing Countries Region to the World (Bond, 1987: 191-227), India's Manufactured Export: An Analysis of Supply Factors (Ali, 1987: 152163), The Demand for LCD Export of Manufactures: Estimates from Hong Kong (Riedel, 1988: 138-148), dan Demand and Supply Factors in the Determinants of NIE Export: A Simultaneous Error-Correction Model for Hong Kong (Muscatelli et al., 1992: 1467-1477).

Dengan mendasarkan pada studi empiris sebelumnya, maka tujuan yang hendak dicapai penulis adalah untuk mengetahui dampak pergeseran struktur ekonomi terhadap perubahan 
ekspor Indonesia, serta menguji validitas teori lqnacy tentang pergeseran struktur ekonomi dalam kaitannya dengan komposisi ekspor; menganalisis dampak perubahan nilai tukar terhadap perubahan ekspor Indonesia, dan menguji tesis Poot, Kuyvenhoven, dan Jansen (1991) tentang peranan penting nilai tukar terhadap perubahan ekspor; menganalisis dan menguji dampak investasi asing terhadap perubahan ekspor Indonesia sebagaimana diungkapkan oleh Booth and Cawley (1982); menganalisis dan menguji teori penawaran ekspor tentang dampak perubahan harga ekspor terhadap perubahan ekspor Indonesia; menganalisis dampak perubahan inflasi yangb bercirikan cost push inflation (Indrawati, 1996) terhadap perubahan ekspor Indonesia; menganalisis dampak pergeseran struktur ekonomi, perubahan nilai tukar, investasi asing, perubahan harga ekspor, dan inflasi secara bersama-sama terhadap perubahan ekspor Indonesia. Namun demikian fokus utama dalam penelitian ini adalah keterkaitan antara kuantitas ekspor dengan pergeseran struktur ekonomi dengan menggunakan dasar pemikiran lqnacy (1980).

\section{TEORI}

Teori lqnacy pada dasarnya mengarah pada analisis dengan menggunakan empat sektor ekonomi, yaitu: sektor yang menghasilkan mesin-mesin dan peralatan-peralatan (sektor M), sektor yang menghasilkan mineral, bahan baku pertanian, dan input seperti pupuk, baja (sektor

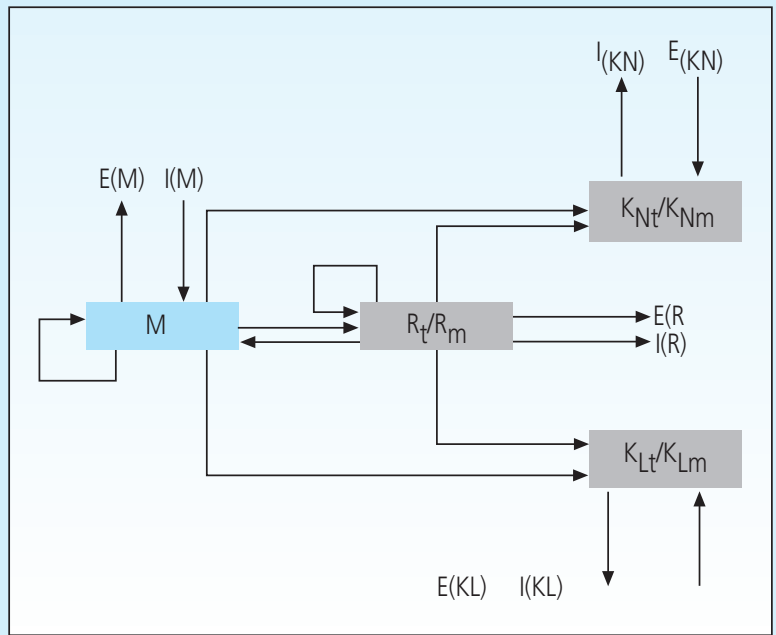

Sumber : Iqnacy (1980): 105.

Gambar IV.1 Hubungan Empat Sektor Ekonomi, Pasar Luar Negeri, Industri dan

Perkembangan Ekonomi 
R), sektor yang menghasilkan barang kebutuhan konsumen utama, seperti makanan (sektor $\mathrm{K}_{\mathrm{N}}$ ), dan sektor yang menghasilkan kebutuhan konsumen lain yang bersifat mewah atau sektor $K_{L}$ (Iqnacy, 1980: 103-105). Di samping itu, Iqnacy juga membuat dikotomi pada sektor $R_{,} K_{N^{\prime}}$ dan $K_{L}$ dalam subsektor tradisional $(\mathrm{t})$ dan modern $(\mathrm{m})$.

Teori mengenai pergeseran struktur pada mulanya timbul dari para ekonom aliran Neo Klasik. Fisher (1939) mengemukakan teori tentang pola pergeseran struktur ekonomi dan didukung oleh kajian data statistik oleh Clark (1940). Teori ini berfokus pada perubahan produksi dan penggunaan faktor produksi yang digunakan dengan hipotesis akan terjadi perubahan nilai produksi dan penggunaan faktor produksi tenaga kerja dengan semakin berkembangnya suatu perekonomian. Pembahasan yang sistematis tentang pergeseran struktur produksi dan struktur kesempatan kerja yang menyertai pertumbuhan ekonomi dimulai oleh Fisher dengan memperkenalkan konsep tentang produksi ke dalam kegiatan primer, sekunder dan tersier. Kegiatan primer meliputi kegiatan ekonomi pada sektor pertanian, peternakan dan pada beberapa versi termasuk pertambangan. Kegiatan sekunder meliputi kegiatan ekonomi pada sektor manufaktur yang pada umumnya menyangkut sektor pertambangan dan konstruksi. Sedang kegiatan tersier meliputi kegiatan ekonomi pada sektor-sektor transportasi dan komunikasi, perdagangan besar dan kecil, pemerintah, jasa-jasa domestik dan personal.

Teori lain mengenai pergeseran struktural yang terkenal adalah teori pola-pola pembangunan dari Chenery. Chenery melakukan studi di banyak negara dan hasil studinya menyimpulkan bahwa pembangunan merupakan suatu proses pertumbuhan dan perubahan yang dapat diamati dimana ciri-cirinya hampir sama untuk semua negara. Pergeseran struktur ekonomi dalam proses pembangunan di suatu negara dapat dibedakan berdasarkan pada persentase tenaga kerja yang berada di sektor primer, sekunder dan tersier. (Syrquin, 1988:212) Taylor dan Chenery (1968) membagi struktur produksi ke dalam sektor primer (pertanian dan pertambangan), sektor industri (industri pengolahan dan bangunan) dan sektor jasa (terdiri dari sisanya). Syrquin dan Chenery (1975) membagi struktur produksi ke dalam empat sektor, yang terdiri dari : sektor primer (pertanian dan pertambangan), sektor industri, sektor unitily (listrik, gas, air minum, pengangkutan dan komunikasi) dan sektor jasa. Selain dari jumlah dan banyaknya sektor, perbedaan lain antara model Chenery dan Syrquin dengan model Chenery dan Taylor terletak pada jumlah dan jenis variabel yang menjelaskan tentang pola pergeseran struktur produksi dengan variabel yang mempengaruhinya.

Clark (1949), mengumpulkan data statistik mengenai persentase tenaga kerja yang bekerja di ketiga sektor diatas. Data yang dikumpulkan itu menunjukkan bahwa semakin tinggi pendapatan per kapita suatu negara, semakin kecil peranan sektor pertanian dalam menyediakan kesempatan kerja. Sebaliknya, sektor industri semakin penting peranannya dalam menampung tenaga kerja. 
Lewis, Fei, Ranis dan Todaro (1969) mengemukakan teori yang sering disebut dengan teori tentang dualisme ekonomi (economic dualism) atau teori tentang interaksi dua sektor (two-sectors interaction). Pada dasarnya teori-teori ini mengelompokan perekonomian ke dalam dua sektor atau bagian yaitu : (i) sektor tradisional/pedesaan/pertanian disatu sisi dan (ii) sektor modern/perkotaan/ industri pada sisi yang lainnya (Ranis, 1988: 76-85; Stiglitz, 1988: 105135). Dalam teori ini ditekankan bahwa proses perkembangan ekonomi akan terjadi interaksi antara kedua sektor atau bagian tersebut dan sekaligus mengakibatkan akan terjadinya perubahan peranan masing-masing sektor dalam perekonomian. Kecenderungan umum yang terjadi adalah semakin berkembang suatu perekonomian, semakin cenderung didominasi oleh peranan sektor modern. Landasan pokok dari teori ini adalah asumsi yang menyatakan bahwa tenaga kerja disektor pertanian tidak terbatas (unlimited of labor). Tenaga kerja dari sektor ini akan berpindah ke sektor modern jika terdapat perbedaan insentif dimana tingkat upah melebihi tingkat upah subsisten di sektor tradisional.

Kuznets (1965) dan beberapa penulis lainnya, telah mengadakan penelitian lebih lanjut mengenai pergeseran struktur ekonomi dalam proses pembangunan. Kuznets bukan saja menyelidiki tentang perubahan persentase penduduk yang bekerja di berbagai sektor dan sub sektor, melainkan juga menunjukkan perubahan sumbangan berbagai sektor kepada produksi nasional (Chenery dan Srinivasan, 1988: 198). Sementara untuk mengetahui bagaimana corak perubahan dalam struktur ekonomi pada masa yang lalu, Kuznets mengumpulkan data mengenai sumbangan berbagai sektor kepada produksi nasional di 13 negara, yang sekarang ini termasuk dalam kelompok negara-negara maju. Kesimpulan yang diperoleh adalah peranan sektor pertanian menurun selama proses pembangunan, sektor industri dalam menghasilkan produksi nasional meningkat, sumbangan sektor-sektor jasa dalam menciptakan produksi nasional mengalami perubahan yang berarti dan bersifat tidak konsisten.

Chenery dan Syrquin (1975), menggambarkan bagaimana corak pergeseran struktur ekonomi yang terjadi dalam proses pembangunan di negara-negara berkembang. Teori ini berkaitan dengan transformasi sektoral pada suatu perekonomian yang sedang berkembang, yang didukung oleh bukti empirik berdasarkan kajian mereka sendiri. Pada dasarnya kajian tersebut menyatakan bahwa dengan semakin meningkatnya pendapatan per kapita suatu negara akan disertai oleh perubahan komposisi output secara sektoral (Syrquin, 1988: 205-214). Corak perubahan komposisi output sektoral tersebut adalah dengan semakin meningkatnya pendapatan per kapita meliputi : (i) proporsi produksi bersih sektor primer cenderung menurun, (ii) proporsi produksi sektor industri cenderung semakin meningkat, (iii) proporsi produksi sektor jasa cenderung semakin meningkat dengan kecepatan yang lepih lambat dibandingkan dengan kecepatan peningkatan pada sektor industri. 
Dua strategi industri penting yang terkait dengan perdagangan adalah produksi barang untuk pasar dalam negeri untuk pengganti barang impor (import substituting industrialization) dan produksi barang untuk pasar luar negeri (export-oriented industrialisation). Banyak negara sedang berkembang mengawali proses industrialisasinya dengan menerapkan industri substitusi impor (ISI), menurut Nafzieger(1997 : 506-508) alasan mengapa negara sedang berkembang menerapkan import substituting industrialization adalah untuk:

1. Menghemat penggunaan devisa;

2. Memperbaiki Neraca Pembayaran;

3. Memenuhi kebutuhan sendiri akan berbagai barang industri;

4. Mengembangkan kegiatan ekonomi dalam negeri.

Kebijakan orientasi ekspor timbul karena kegagalan strategi ISI. Kaum Neo $\neq$ Klasik mengemukakan bahwa penerapan strategi orientasi ekspor akan memberi hasil yang lebih unggul, dalam arti efisiensi alokasi dan pertumbuhan ekonomi (Gammel, 1994: 102-103).

Studi yang dilakukan mulai dari Tyler (1981), Jung dan Marshall (1985), Basmani-Oskooee dan Alse (1993), Dodaro (1993) dan pakar ekonomi lainnya yang mendukung hipotesis bahwa ekspor sebagai lokomotif pembangunan ekonomi suatu negara. Kegiatan dan peningkatan ekspor merupakan suatu insentif bagi pertumbuhan dan kemajuan sektor-sektor lain. Pertumbuhan ekspor menimbulkan permintaan baru di negara-negara pengekspor baik bagi input dalam pertukaran produksi maupun sebagai hasil peningkatan pendapatan faktor-faktor peroduksi. Perluasan ekspor mampu menghasilkan pertumbuhan ekonomi melalui rangsangan permintaan terhadap sektor lain (Balassa, 1985; Wong, 1986; Sprout dan Weaver, 1993).

Krugman (1994) menyatakan bahwa tujuan suatu negara melakukan perdagangan internasional adalah untuk mendapatkan keuntungan dan mencapai skala ekonomis (economies of scale) dalam produksi. Perdagangan dapat menciptakan keuntungan dengan memberikan peluang untuk mengekspor barang-barang yang diproduksi dengan sumber daya yang melimpah. Perdagangan juga memungkinkan setiap negara melakukan spesialisasi produksi pada barang-barang tertentu untuk mencapai tingkat efisiensi yang tinggi dan skala produksi yang besar.

Merujuk problematika perdagangan tersebut, teori Heckscher-Ohlin $(\mathrm{H}-0)$ sering menjadi obyek pengujian empiris untuk memperkirakan dampak perdagangan terhadap distribusi pendapatan dan pola perdagangan. Berdasarkan intensitas faktor produksi, H-O (1933) mengemukakan model dua faktor produksi dari dua negara dengan dua komoditas, yaitu komoditas padat karya dan komoditas padat modal. Kekayaan relatif akan modal fisik akan menyebabkan produksi dan ekspor didominasi oleh barang padat karya/tenaga kerja. Disamping 
itu suatu negara yang mempunyai tenaga trampil akan mempunyai keunggulan komparatif dalam produksi dan ekspor komoditas padat keahlian (Ballasa, 1988: 10).

Hipotesis technological gap diajukan oleh Postner tahun 1961, dengan menggunakan rangkaian inovasi dan imitasi yang mempengaruhi ekspor. Ketika produk baru berkembang dan mulai menguntungkan di pasar domestik, perusahaan yang melakukan inovasi untuk sementara waktu memperoleh keuntungan monopoli. Sehingga dengan mudah memasuki pasaran internasional karena masalah entry lag. Keuntungan yang kian meningkat pada gilirannya akan merangsang imitasi di negara lain, terutama kalau inovasinya telah didesimilasi. Untuk memiliki keunggulan dalam mengekspor, negara yang bersangkutan harus selalu mengusahakan terjadinya inovasi. Sebagaimana tesis Linder, hipotesis Postner secara implisit dapat dikategorikan sebagai teori spillover, yakni ekspor baru akan terjadi kalau konsumsi domestik telah terpenuhi. Banyak bukti menunjukkan bahwa pola sedemikian tidak selalu terjadi. Kelemahan lainnya, baik Postner maupun Linder tak dapat memberikan alasan tentang tahaptahap sejak dari inovasi hingga imitasi dan lamanya proses tersebut (Basri, 1991: 23).

Selanjutnya, Vernon menjeneralisasi pemikiran tersebut dalam Product Life Cycle Theory (PLC). Teori ini tidak menganggap variabel dalam perekonomian sebagai fixed dan exogeneous, tetapi variabel-variabel tersebut senantiasa berubah dan perubahannya terjadi di dalam model dan menggunakan perubahan variabel $\neq$ variabel tersebut sebagai driving motives timbulnya perdagangan internasional, karena itu teori PLC disebut sebagai teori dinamik.

\section{METODOLOGI}

Jenis data yang digunakan dalam penelitian ini adalah data sekunder yang diperoleh dari berbagai lembaga dan instansi, antara lain berasal dari Nota Keuangan Rencana Anggaran dan Belanja Negara, Statistik Ekonomi dan Keuangan Indonesia-BI, Statistik Indonesia-BPS, dan International Financial Statistics-IMF serta berbagai penerbitan lain yang mendukung dan berhubungan dengan penelitian ini. Semua data yang diambil adalah data runtut waktu (time series) kuartalan untuk periode pengamatan tahun 1983 kuartal I hingga 1997 kuartal IV.

Spesifikasi model empiris penawaran ekpor diformulasikan sebagai berikut:

$$
\boldsymbol{X}=\beta_{0}+\beta_{1} \boldsymbol{P X}+\beta_{2} \boldsymbol{I N F}+\beta_{3} \boldsymbol{E R}+\beta_{4} \boldsymbol{T S E}+\beta_{5} I N \boldsymbol{V}+\varepsilon t
$$




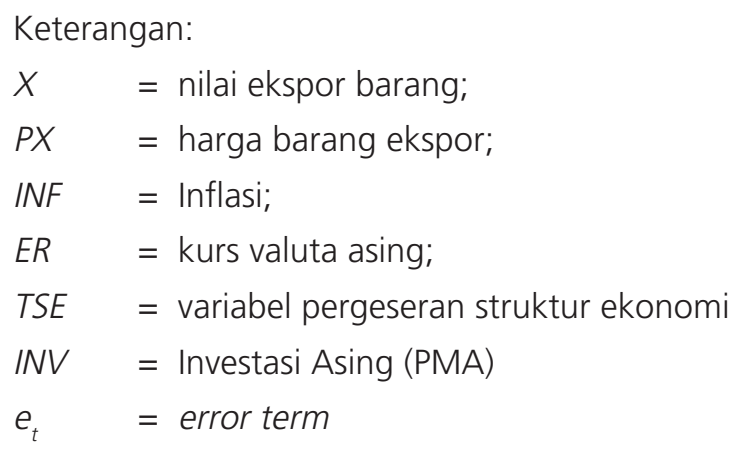

Kecuali variable inflasi, semua variable dalam persamaan di atas diberikan dalam bentuk logaritma natural. Transformasi tersebut membawa beberapa keuntungan, antara lain, dari derivasi tingkat pertama dapat diketahui angka elastisitas, yang nilainya sebesar koefisien variable yang bersangkutan, dan kentungan kedua, akan memperbaiki pengujian statistik yang dilakukan. Sebagai catatan, variabel INF tidak termasuk dalam variabel yang ditransformasikan dalam bentuk logaritma natural karena inflasi merupakan bentuk perubahan dari variabel harga, yang mungkin bernilai negatif sehingga tidak akan mungkin dilogaritmakan.

Teknik estimasi yang dapat digunakan adalah Ordinary Least Square (OLS) apabila asumsi linearitas, homoscedasticity, tidak adanya serial korelasi dan multikolinearitas dapat terpenuhi (Engle and Granger, 1987; Mukherjee and Naka, 1995; Masih and Masih, 1996). Dalam kondisi asumsi tersebut gagal terpenuhi, contohnya terdapat kasus heteroscedasticity, maka teknik estimasi Weighted Least Square (WLS) menjadi pilihan untuk diterapkan.

Sebelum estimasi dilakukan, pengujian stasioneritas dilakukan untuk setiap variabel yang terlibat dalam model, dengan menggunakan metode Dickey-Fuller (DF) dan metode PhillipPerron (PP). Sesuai dengan sifat alamiah dari variabel yang bersangkutan, pengjian stasioneritas dapat berbentuk memiliki pengaruh trend atau $\operatorname{ADF}(T, n)$, hanya memiliki konstanta ADF $(C, n)$, dan adanya white-noise error term atau $\operatorname{ADF}(N, n)$ (Gujarati, 1995: 718). Dalam kondisi variabel tidak stastioner, maka prosedur standar yang dapat dilakukan adalah dengan mendiferensiasi variabel tersebut, hal ini berguna untuk menghindari terjadinya spurious regression.

Terdapat kemungkinan bahwa variabel-variabel yang tidak stasioner dalam level, mungkin memiliki hubungan jangka panjang. Dalam hal ini, variabel-variebel tersebut dikatakan terkointegrasi. Pengujian kointegrasi ini dapat dilakukan dengan uji Engle-Granger Cointegration Regression Durbin-Watson (CRDW). Jika derajat diferensiasi setiap variabel tersebut sama, maka spesifikasi model dapat mengarah pada Error Correction Model (ECM) untuk satu variabel dependen atau Vector Error Correction Model (VECM) untuk serangkaian persamaan dengan jumlah variabel dependen yang lebih dari satu. Dengan lain perkataan, uji kointegrasi dapat 
dijadikan dasar penentuan estimasi persamaan yang digunakan memiliki keseimbangan dalam jangka panjang atau tidak. Apabila persamaan estimasi lolos dari uji ini maka persamaan estimasi tersebut memiliki keseimbangan jangka panjang (Thomas, 1997: 425).

Masih terkait dengan aspek stasioneritas ini, kemungkinan lainnya adalah ketika setiap variabel yang terlibat dalam model ternyata stasioner pada derajat diferensiasi yang berbeda. Dalam kondisi ini, maka alternative model yang dapat diterapkan adalah Autoregressive Distributed Lag (ARDL). Model ini juga dapat dikembangkan menjadi model ARDL-ECM untuk lebih mengkaji perbedaan karakteristik keseimbangan jangka pendek dan jangka panjang dari variabel-variabel yang diteliti.

Validasi atas model dapat dilakukan dengan pengujian CUSUM yang menguji stabilitas model. Selain itu, validasi model juga dapat dilakukan dengan melihat kemampuan model tersebut dalam mereplikasi kejadian aktual (model fitting), daya prediksi atas kejadian masa lampau (backcasting) dan kemampuannya untuk melakukan peramalan masa mendatang (forecasting).

\section{HASIL DAN ANALISIS}

Pengujian stasioneritas menunjukkan bahwa variabel memiliki derajad stasioneritas yang berbeda-beda. Sebagimana disebutkan sebelumnya, perbedaan derajad stasioneritas ini dapat saja mengakibatkan persamaan estimasi OLS tetap memiliki sifat stasioneritas dalam persamaan (Gujarati, 1995: 726-727). Oleh sebab itu, langkah selanjutnya adalah melakukan uji kointegrasi, yaitu uji stasioneritas pada persamaan estimasi.

\begin{tabular}{|l|c|l|c|}
\hline \multicolumn{4}{|c}{ Tabel IV.1. } \\
\hline Variable & Coefficient & t-Statistic & Prob. \\
\hline C & 6.7181 & 8.6270 & 0.000 \\
LPX & 0.1430 & 2.1381 & 0.037 \\
INF & 0.0004 & 0.0716 & 0.943 \\
LER & 0.0223 & 0.2816 & 0.779 \\
LTSE & 1.6393 & 11.8601 & 0.000 \\
LINV & 0.0284 & 1.0695 & 0.289 \\
R-squared & 0.971 & F-statistic & 356.90 \\
Adjusted R-squared & 0.967 & Prob(F-statistic) & 0.000 \\
Durbin-Watson stat & 0.458 & & \\
\hline Keterangan: Angka statistik CRDW 1\% $=0.511 ; 5 \%=0.38 ; 10 \%=0.322$ \\
\hline
\end{tabular}


Tabel IV.1 menunjukkan bahwa persamaan OLS LX= $f(L P X, I N F, L E R, L T S E, ~ L I N V)$ menunjukkan adanya kecenderungan terkointegrasi pada taraf $5 \%$. Kesimpulan tersebut didasarkan pada angka statistik Durbin-Watson persamaan estimasi yang sebesar 0,458. Dengan demikian, persamaan $L X=f(L P X, I N F, L E R, L T S E$, LINV) merupakan persamaan keseimbangan jangka panjang yang memiliki bentuk persamaan:

$$
\begin{aligned}
& L X=6.718+0.143 L P X+0.0004 I N F+0.022 L E R+1.639 L T S E+0.028 L I N V \\
& \begin{array}{lrrrrr}
(8.63) & (2.14) & (0.07) & (0.28) & (11.86) & (1.07) \\
(p=0.00) & (0.04) & (0.94) & (0.78) & (0.00) & (0.29)
\end{array}
\end{aligned}
$$

Dalam pengujian kointegrasi, terdapat sedikit perbedaan antara model kointegrasi EngleGranger CRDW dengan Johansen. Model Johansen lebih memfokuskan diri pada kointegrasi pada sistem persamaan (system equation) dan bukan pada persamaan tunggal (single equation) sebagaimana Engle-Granger CRDW. Dibandingkan dengan Engle-Granger CRDW, model Johansen tidak menuntut adanya sebaran data yang normal (Phillips, 1991; Mukherjee and Naka, 1995).

\begin{tabular}{c|c|c}
\multicolumn{2}{c}{ Rekapitulasi Uji Kointegrasi Johansen } \\
\hline Type Kointegrasi Johansen & $\begin{array}{c}\mathbf{H}_{0} \text { : No Cointegration } \\
\text { Estimation }\end{array}$ & $\begin{array}{c}\mathbf{H}_{\text {a: } \text { Cointegration }} \\
\text { Estimation }\end{array}$ \\
\hline $\begin{array}{c}\text { Test assume no deterministic trend in } \\
\text { data: no intercept or trend in CE }\end{array}$ & Reject & $\begin{array}{c}\text { Do not reject } \\
\text { (2 cointegrating equation) }\end{array}$ \\
\hline $\begin{array}{c}\text { Test assume no deterministic trend in } \\
\text { data: with intercept (no trend) in CE }\end{array}$ & Reject & $\begin{array}{c}\text { Do not reject } \\
\text { (2 cointegrating equation) }\end{array}$ \\
\hline $\begin{array}{c}\text { Test allows for linear deterministic trend } \\
\text { in data: intercept (no trend) in CE }\end{array}$ & Reject & $\begin{array}{c}\text { Do not reject } \\
\text { (2 cointegrating equation) }\end{array}$ \\
\hline $\begin{array}{c}\text { Test allows for linear deterministic trend } \\
\text { in data: intercept (no trend) in CE }\end{array}$ & Reject \\
\hline $\begin{array}{c}\text { Test allows for quadratic deterministic } \\
\text { trend in data: intercept and trend in CE }\end{array}$ & Reject & $\begin{array}{c}\text { Do not reject } \\
\text { (1 cointegrating equation) }\end{array}$ \\
\hline
\end{tabular}

Keterangan: Angka statistik CRDW 1\% $=0.511 ; 5 \%=0.38 ; 10 \%=0.322$

Dari hasil pengujian kointegrasi Johansen dengan menggunakan berbagai asumsi, terlihat bahwa hasil tersebut memiliki konsistensi dari sisi ada atau tidaknya kointegrasi. Secara ringkas hasil pengujian kointegrasi Johansen dapat dilihat pada Tabel IV.2. 


\section{IV.1. Hasil Perhitungan Error Correction Model (ECM)}

Model dinamis yang dalam beberapa tahun terakhir mendapat perhatian besar dari kalangan ekonom adalah model koreksi kesalahan (the error correction model/ECM). Dalam dunia nyata terlihat bahwa pelaku ekonomi bereaksi tidak spontan dalam menanggapi aksi. Hal ini merupakan alasan dibentuknya model dinamis khususnya model koreksi kesalahan. Eksistensi koreksi kesalahan menghasilkan koefisien koreksi kesalahan yang menunjukkan adanya fenomena dikoreksinya penyimpangan menuju ekuilibrium. Dengan ECM dapat diketahui apakah variabel-variabel yang diamati berkointegrasi. Hal ini ditunjukkan dengan error correction term yang signifikan, atau dengan kata lain model koreksi kesalahan sahih (valid) dan variabel yang diamati berkointegrasi. Hasil perhitungan dengan menggunakan ECM adalah sebagai berikut:

$$
\begin{aligned}
& \mathrm{d}(\boldsymbol{L X})=-0.259+0.02 \mathrm{~d}(\boldsymbol{L P X})-0.0001 \mathrm{~d}(\boldsymbol{I N F})-0.063 \mathrm{~d}(\boldsymbol{L E R})+0.632 \mathrm{~d}(\boldsymbol{L T S E}) \\
& \begin{array}{llll}
(-0.45) \quad(0.709) \quad(-0.004) \quad(-1.041) \quad(3.843)
\end{array} \\
& \begin{array}{lllll}
p=0.655) & (0.482) \quad(0.999) \quad(0.303) \quad(0.00)
\end{array} \\
& +0.013 \mathrm{~d}(\boldsymbol{L I N} \boldsymbol{V})-0.047 \text { LPX }(-1)-0.06 \text { INF(-1) + } 0.016 \text { LER(-1) } \\
& (-0.989) \quad(-0.791) \quad(-1.134) \quad(-0.211) \\
& \begin{array}{llll}
(0.328) & (0.433) & (0.263) & (0.834)
\end{array} \\
& +0.079 \operatorname{LTSE}(-1)+0.059 \operatorname{LINV}(-1)+0.073 \boldsymbol{E C T} \\
& (0,973) \quad(1.038) \quad(1.261) \\
& \begin{array}{lll}
(0.335) & (0.304) \quad(0.214)
\end{array}
\end{aligned}
$$

Ramsey RESET $=1.162(0.287)$

Dari hasil penghitungan ECM dapat disimpulkan bahwa model ECM tersebut memiliki kelemahan dalam pengujian diagnostiknya. Khususnya untuk uji normalitas Jarque-Bera dan uji heteroskedastisitas White.

Dugaan yang dapat dibuat berdasarkan kelemahan uji diagnostik tersebut adalah adanya indikasi kuat tidak terpenuhinya asumsi homoschedasticity, sebagaimana model dasar OLS sebagaimana ditunjukkan pada bagian terdahulu. Dengan demikian, sebagaimana pemecahan persoalan heteroschedasticity, maka akan digunakan prosedur WLS untuk kedua model ECM tersebut. 


\section{IV.2. Weighted Least Square Pada Model ECM}

Dari indikasi yang terlihat bahwa model estimasi ECM juga mengalami gejala heteroschedasticity, maka model ECM akan dilakukan dengan menggunakan prosedur WLS untuk mengeliminasi efek dari heteroschedaticity. Hasil estimasi dengan menggunakan WLS untuk model ECM adalah sebagai berikut:

$$
\begin{aligned}
& \mathrm{d}(\boldsymbol{W L X})=0.055+0.423 \mathrm{~d}(\boldsymbol{W L P X})-0.002 \mathrm{~d}(\boldsymbol{W I N F})+0.847 \mathrm{~d}(\boldsymbol{W L E R}) \\
& \begin{array}{lccc}
(0.050) & (6.253) & (-0.261) & (16.138) \\
(p=0.960) & (0.000) & (0.795) & (0.000)
\end{array} \\
& +0.899 \mathrm{~d}(\boldsymbol{W L T S E})+0.003 \mathrm{~d}(\boldsymbol{W L I N V})+0.256 \boldsymbol{W L P X}(-1) \\
& \text { (9.021) (0.024) (-5.708) } \\
& \text { (0.000) (0.981) (0.000) } \\
& \text { - 0.599 WINF(-1) - } 0.145 \text { WLER(-1) + } 0.065 \text { WLTSE }(-1) \\
& \begin{array}{lcc}
(-6.336) & (-2.969) & (0.735) \\
(0.000) & (0.005) & (0.466)
\end{array} \\
& +0.032 \text { WLINV }(-1)+0.603 \text { WECT } \\
& \text { (0.087) (0.000) }
\end{aligned}
$$

$$
\begin{array}{llr}
R-S q r=0.99 ; & D W R=1.499 ; & F=10.447 \\
\text { Jarque-Bera }\left(\chi^{2}\right)=0.756(0.685) & \text { Serial Correlation }(F-\text { Test }))=1.261(0.300) \\
\text { ARCH }(\text { F-Test })=1.114(0.360) & \text { White's Test }(\text { F-Test }) \quad=0.238(0.101)
\end{array}
$$

Ramsey RESET (F-Test) $=0.731(0.575)$

Interpretasi hasil perhitungan ECM dengan penimbang dapat dilakukan dengan pembedaan interpretasi antara jangka pendek dan jangka panjang. Dalam jangka pendek interpretasi difokuskan pada variabel analisis yang diderivasi pada tingkat pertama, yaitu d(LPX), $d(I N F), d(L E R), d($ LTSE), dan d(LINV). Sedangkan untuk jangka panjang dapat dilihat dari variabel yang diperlakukan sebagai backward lag operator, yaitu LPX(-1), INF(-1), LER(-1), LTSE(-1) dan LINV(-1). Namun, khusus untuk jangka panjang, koefisien yang akan ditafsir harus terlebih dahulu di bagi dengan koefisien ECT.

Dalam jangka pendek hasil perhitungan ECM dengan penimbang dapat diinterpretasikan sebagai berikut:

- Apabila variabel tingkat harga ekspor mengalami perubahan sebesar 1\% akan berdampak pada peningkatan volume ekspor sebesar $0.42 \%$ (inelastis) dengan seignifikansi $0 \%$ (kuat) 
- Apabila variabel inflasi domestik mengalami penurunan sebesar 1\% tidak akan banyak berpengaruh pada volume ekspor karena koefisien sangat kecil dan signifikansinya sangat lemah (79\%)

- Apabila terjadi penurunan nilai tukar Rupiah terhadap US Dollar sebesar 1\% maka akan terjadi peningkatan volume ekspor sebesar $0.847 \%$ (inelastis) dengan signifikansi yang kuat (0\%)

- Apabila terjadi pergeseran struktur ekonomi sebesar 1\% dalam artian perubahan sektor industri lebih besar 1\% dibandingkan dengan sektor pertanian, maka akan berdampak sangat kuat pada peningkatan volume ekspor sebesar $0.899 \%$ (elastis) dengan signifikansi yang kuat $(0 \%)$

- Sedangkan variabel perubahan investasi asing berpengauh positif terhadap kuantitas ekspor namun pengaruhnya secara statistik sangan lemah (98\%)

$$
L X=0.091+0.425 W L P X-0.994 \text { WINF }-0.239 \text { WLER }+0.1079 \text { WLTSE }+0.005 \text { WLINV }
$$

Dalam jangka panjang ECM dengan penimbang dapat diformulasikan sebagai berikut:

Perhitungan tersebut dapat diinterpretasikan sebagai berikut:

- Apabila terjadi peningkatan harga produk ekspor sebesar 1\% maka volume ekspor akan meningkat sebesar $0.425 \%$

- Apabila terjadi peningkatan inflasi sebesar $1 \%$ maka volume ekspor akan menurun sebesar $0.994 \%$

- Apabila terjadi peningkatan nilai tukar Rupiah terhadap US Dollar (apresiasi) maka volume ekspor akan menurun sebesar 0.239\%

- Apabila terjadi perubahan struktural yang diakibatkan oleh kenaikan sektor industri 1\% lebih besar daripada sektor pertanian, maka volume ekspor akan meningkat $0.108 \%$

- Variabel investasi asing menunjukkan pengaruh positif dan signifikan pada taraf $8 \%$. Bila investasi naik 1\% maka akan mengakibatkan kenaikan jumlah ekspor sebesar $0.54 \%$

\section{IV.3. Pembahasan}

Hubungan ekspor dengan tingkat harga ekspor dalam jangka pendek menunjukkan hubungan positif, dapat diartikan dalam jangka pendek kenaikan harga di pasar internasional akan membawa dampak peningkatan jumlah ekspor. Peningkatan jumlah ekspor ini dimungkinkan terjadi karena kenaikan harga dapat lebih cepat terjadi dibandingkan dengan perubahan variabel lain yang mungkin berdampak sebaliknya, sehingga diperlukan waktu untuk 
mencapai keseimbangan baru. Dalam jangka panjang terdapat kecenderungan peningkatan harga akan menurunkan perubahan ekspor. Temuan ini menunjukkan bahwa pasar internasional sangat kuat dibandingkan dengan posisi tawar menawar eksportir.

Tingkat inflasi berperan besar dalam perkembangan volume ekspor. Apabila inflasi sebagai perubahan indeks harga konsumen, maka faktor pendorong menurunnya ekspor adalah demand domestic pull. Bila terjadi kenaikan permintaan domestik yang lebih tinggi daripada kenaikan permintaan luar negeri maka terdapat kecenderungan komoditi akan memenuhi pasaran domestik. Hal ini didasarkan atas pertimbangan bahwa terjadinya kenaikan relatif permintaan domestik terhadap permintaan luar negeri maupun produksi komoditi akan menyebabkan kenaikan harga komoditi tersebut di dalam negeri. Adanya kecenderungan terjadinya kekakuan harga upah, yang merupakan elemen penting dalam produksi, maka kenaikan harga komoditi tersebut tidak diikuti oleh kenaikan ongkos produksi. Dengan demikian margin keuntungan produsen akan semakin lebar di pasaran domestik. Margin keuntungan domestik tersebut dianggap sebagai dorongan bagi produsen untuk meningkatkan penawarannya di pasar domestik. Keterbatasan kapasitas produksi dalam jangka pendek untuk mengikuti perkembangan pasar menyebabkan peningkatan penawaran di pasar domestik hanya akan tercapai bila mengurangi penawaran ekspor komoditi tersebut. Inilah penyebab penurunan ekspor dalam jangka pendek.

Dalam jangka panjang, dampak inflasi dapat dianggap sebagai faktor yang akan meningkatkan tingkat biaya produksi, dengan telah terpengaruhnya tingkat upah dan variabel input lainnya. Peningkatan biaya produksi tersebut diartikan sebagai peningkatan dalam harga komoditi, dengan demikian, dalam jangka panjang insentif harga domestik tidak dapat dipertahankan lagi. Bila produsen akan meningkatkan kembali aksesnya di pasar internasional, maka produsen berhadapan dengan harga yang relatif lebih tinggi daripada sebelumnya.

Uraian tersebut menyisakan pertanyaan penting, yaitu bila harga ekspor - volume ekspor, dalam jangka pendek menunjukkan hubungan positif mengapa dalam hubungan antara inflasi - volume ekspor menunjukkan hubungan negatif, padahal inflasi berpengaruh positif atau akan mendorong kenaikan harga. Penjelasannya adalah sebagai berikut, dalam jangka pendek terdapat asumsi kemampuan produsen untuk meningkatkan kapasitas produksi terbatas karena adanya unsur kekakuan perubahan harga maupun kuantitas penggunaan input tambahan, namun fleksibilitas peningkatan kapasitas produsen dapat dicapai bila produsen bekerja dalam kapasitas yang lebih besar daripada permintaan. Dengan kata lain, produsen menerapkan reserve capacity yang dijadikan sebagai cara untuk mengantisipasi perubahan permintaan konsumen yang bersifat mendadak. Pada waktu yang bersamaan, ketika harga internasional naik dan di dalam negeri terdapat peningkatan inflasi maka produsen akan memiliki kemampuan untuk 
menyesuaikan kapasitas produksi secara cepat tanpa mendapat kesulitan karena faktor kekakuan harga guna meningkatkan pasokan domestik dan sekaligus pasokan internasional.

Hubungan ekspor dengan perubahan nilai tukar dalam jangka panjang adalah negatif. Dampak negatif merosotnya nilai tukar rupiah terhadap US Dollar dirasakan oleh produsen bila barang input yang dimiliki banyak tergantung pada barang impor. Karena depresiasi nilai rupiah, produsen membayar lebih banyak uang dalam bentuk rupiah daripada sebelumnya. Kesulitan memperoleh input yang berasal dari luar negeri inilah yang pada akhirnya akan menghambat pengembangan produksi. Namun hambatan terhadap ekspor tersebut terjadi pada jangka panjang, karena produsen menikmati murahnya mata uang rupiah selama produsen memiliki persediaan input impor. Perubahan yang terjadi dalam jangka pendek pada nilai tukar berdampak pada daya saing harga dari produk-produk ekspor Indonesia. Bila nilai tukar rupiah menurun terhadap US Dollar, maka harga produk ekspor Indonesia ke luar negeri dalam bentuk US Dollar, menghasilkan rupiah yang lebih besar. Mekanisme ini berdampak positif bagi eksportir karena rupiah yang diperolehnya dapat mendorong kemampuan produksi. Dampak ini hanya berjangka pendek karena pasar akan sampai pada keseimbangannya yang baru.

Grafik IV.1 , memperlihatkan time lag perubahan nilai tukar dengan perubahan volume ekspor. Pada tahun 1983 ketika rupiah terapresiasi dalam kurun waktu kurang lebih satu semester nilai ekspor meningkat tapi tidak terlalu tinggi kemudian mengalami penurunan yang cepat pada 1984-1986. Tahun 1986, ketika pemerintah mendevaluasi rupiah, volume ekspor tidak otomatis meningkat namun membutuhkan waktu kurang lebih tiga bulan untuk bereaksi. Kurang lebih enam bulan kemudian volume ekspor berada pada posisi rata-rata. Pada saat itu

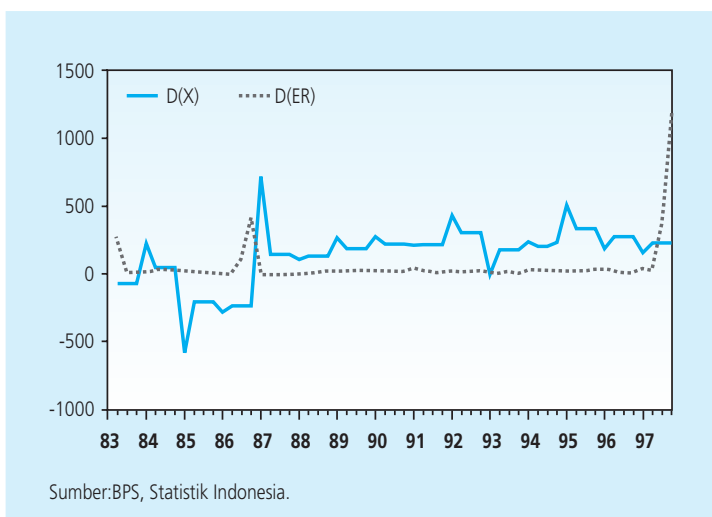

Grafik IV.1 Hubungan Antara Variabel Ekspor dengan Nilai Tukar 
pasar input domestik telah bereaksi terhadap perubahan. Disamping itu, persediaan input impor telah kehilangan pengaruh positifnya terhadap volume ekspor karena produsen membeli input yang berasal dari impor dengan harga rupiah yang baru.

Rendahnya tingkat signifikansi pergeseran struktur ekonomi dalam mempengaruhi volume ekspor dapat diartikan sebagai tidak berartinya perubahan volume ekspor dalam jangka panjang. Dugaan yang dapat dibuat berdasarkan fakta jangka panjang tersebut adalah banyak output industri yang juga dilempar ke pasar domestik. Semakin tingginya pendapatan masyarakat, sebagai akibat pergeseran struktur ekonomi tersebut, masyarakat akan mengkonsumsi jumlah output industri yang lebih banyak. Pergeseran struktur ekonomi yang dimaksud dalam penelitian ini adalah pergeseran sektoral yang terjadi pada pendapatan kotor nasional dari sisi produksi. Pergeseran yang terjadi pada perekonomian Indonesia adalah pergeseran dari dominasi sektor pertanian terhadap GDP menjadi dominasi sektor industri.

Pergeseran struktur ekonomi tersebut membawa dampak jenis komoditas yang diekspor maupun yang diimpor. Banyak negara yang menggunakan sektor industri sebagai jalan menuju ke percepatan pertumbuhan ekonomi. Pilihan tersebut didasarkan pada alasan bahwa output yang dihasilkan oleh sektor industri memiliki nilai tambah yang relatif besar bila dibandingkan dengan sektor pertanian. Tingginya nilai tambah sktor industri tersebut maka semakin banyak output sektor industri yang dihasilkan maka akan semakin tinggi pula GDP akan terbentuk.

Karena alasan serupa maka output sektor industri juga diarahkan ke pasaran luar negeri atau ekspor, terdapat hubungan positif antara pergeseran struktur ekonomi, yang secara lebih spesifik dapat disebut industrialisasi, dengan volume ekspor. Semakin tinggi bagian GDP yang berasal dari sektor industri, akan semakin tinggi output sektor industri yang akan dilempar ke pasar ekspor yang berarti pula ekspor didominasi sektor industri.

Kebijakan investasi yang mampu mendorong ekspor non-migas, yang kemudian dikenal dengan Paket 6 Mei, efektif diumumkan pada tahun 1986. Paket 6 Mei tersebut pada dasarnya memiliki beberapa point penting, yaitu mendorong usaha yang sekurang-kurangnya $85 \%$ outputnya diekspor dalam bentuk pengadaan input impor dengan biaya murah melalui subsidi, memberikan fasilitas pinjaman dana bank bila sekurang-kurangnya 75\% equity dimiliki oleh orang Indonesia, bila sekurang-kurangnya $51 \%$ equity ditawarkan di Jakarta Stock Exchange, dan bila sekurang-kurangnya $51 \%$ equity dimiliki oleh orang Indonesia plus sekurang-kurangnya $51 \%$ equity yang ditawarkan $20 \%$ diantaranya ditawarkan di Jakarta Stock Exchange (Poot, Kuyvenhoven, Jansen, 1991: 236-238).

Setelah melalui berbagai revisi kebijakan investasi tersebut, dapat terlihat bahwa sejak periode 1986 terjadi peningkatan realisasi investasi. Sebagaimana terlihat pada Grafik III.2 , 
peningkatan laju pertumbuhan realisasi investasi asing (PMA) maupun PMDN terjadi sejak periode 1985/1987. Periode sebelum adanya kebijakan investasi hanya tumbuh 19,43\% untuk PMDN dan 4,26\% untuk PMA maka dalam periode setelah adanya kebijakan Paket 6 Mei, yang diasumsikan benar-benar efektif terjadi setelah satu tahun berjalan, PMDN tumbuh 18,91\% pada satu tahun setelah kebijakan dan PMA tumbuh dengan 27,12\%. Peningkatan tersebut berlanjut hingga mencapai puncaknya pada tahun 1989/1991, PMDN tumbuh dengan 92,63\% dan PMA tumbuh dengan 42,17\%.

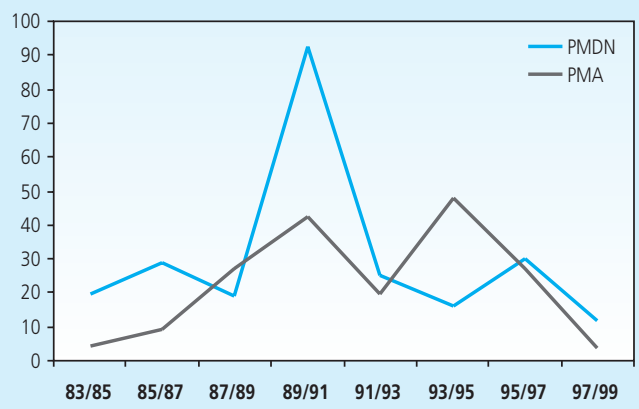

Sumber: Bank Indonesia, SEKI.

\section{Grafik IV.2 : Perkembangan Realisasi PMA dan PMDN (\% dari Total Investasi)}

Dampak kebijakan Paket 6 Mei adalah meningkatnya nilai ekspor. Hasil perhitungan mengindikasikan bahwa kebijakan tersebut direspon positif oleh para investor, khususnya investor sektor industri, karena investor menginginkan pemerintah memberikan prioritas pada sektor tersebut sebagai leading sektor.

Perkembangan ekspor periode 1983-1985 mengalami kelesuan karena perkembangan ekonomi internasional yang dihadapi Indonesia tidak mendukung bagi perkembangan ekspor andalan Indonesia, yaitu migas. Harga migas mengalami kejatuhan pada tahun 1984/1985, yang mengakibatkan ekspor migas menurun secara drastis pada rentang waktu 1986 - 1989. Tercatat penurunan ekspor migas tersebut mencapai $\pm 10 \%$ per-tahun dalam kurun waktu lima tahun (1984 - 1989). Hal inilah yang mendorong pemerintah untuk mengembangkan ekspor non-migas, yang hanya dapat tercapai bila terdapat peningkatan investasi untuk sektor nonmigas, terutama sektor industri.

Grafik IV.3 terlihat bahwa terdapat kebangkitan sektor diluar migas dalam bentuk peningkatan ekspor. Dampak dari kebijakan investasi terhadap peningkatan ekspor memang 
tidak dapat berlangsung seketika. Faktor perbedaan waktu antara kebijakan dan hasil yang dicapai yang hanya sekitar 1 - 2 tahun dapat dijadikan indikator bahwa sektor industri yang cepat bereaksi terhadap peningkatan investasi adalah sektor industri yang tidak padat modal atau padat teknologi. Hal ini dapat dibuktikan dengan peningkatan yang tajam untuk sektor industri kelompok barang SITC-6, sektor industri menurut bahan, yang didalamnya terdapat komoditas plywood dan tekstil.



Sumber: Biro Pusat Statistik.

\section{Gambar IV.3. Perkembangan Volume Ekspor Non-Migas}

Posisi strategis industri plywood dan tekstil dalam pengembangan ekonomi suatu negara. Industri tersebut, khususnya industri tekstil, memiliki backward linkage dan forward linkage yang panjang, merupakan daya tarik untuk dikembangkan di negara sedang berkembang.

\section{KESIMPULAN DAN SARAN}

Dari hasil pembahasan yang telah diuraikan pada bab terdahulu dapat diambil kesimpulan sebagai berikut:

1. Berdasarkan metode analisis yang dikembangkan, yaitu Error Correction Model yang dioperasikan dengan menggunakan Weighted Least Square diperoleh hasil variabel harga ekspor (PX) dalam jangka pendek menunjukkan pengaruh positif dan signifikan untuk menjelaskan perubahan volume ekspor agregat. Sedangkan dalam jangka panjang variabel harga ekspor justru berpengaruh negatif (dan signifikan) terhadap volume ekspor agregat Hasil ini menunjukkan posisi eksportir Indonesia sebagai penerima harga (price taker). Hasil pengamatan jangka panjang menunjukkan kesesuaian hasil dengan pengamatan Marian E. Bond (1987). 
2. Variabel tingkat inflasi dalam jangka pendek tidak dapat menjelaskan perubahan yang dialami oleh volume ekspor agregat, sedangkan inflasi dalam jangka panjang memiliki pengaruh negatif yang kuat untuk mempengaruhi perubahan volume eskpor sebagaimana temuan Goldstein and Khan (1978). Temuan ini dapat diartikan bahwa peningkatan inflasi akan menurunkan ekspor melalui mekanisme peningkatan harga produksi yang berakibat pada penurunan daya saing produk ekspor.

3. Variabel perubahan nilai tukar dalam jangka pendek memiliki pengaruh positif dan signifikan sedangkan dalam jangka panjang memiliki pengaruh negatif. Penurunan nilai tukar mata uang domestik (depresiasi) akan mendorong ekspor dalam jangka pendek sedangkan dalam jangka panjang penurunan nilai tukar (depresiasi) justru akan menurunkan perubahan ekspor. Dalam pengamatan jangka pendek sesuai dengan hasil pengamatan Bond (1978); Riedel (1988).

4. Berbeda dengan studi-studi tentang pergeseran struktur ekonomi yang lain, penelitian ini mengungkapkan persoalan yang relatif baru yaitu peranan pergeseran struktur ekonomi dalam mendorong perubahan ekspor. Variabel pergeseran struktur ekonomi membawa dampak positif terhadap perubahan volume ekspor dalam jangka pendek. Sedangkan dalam jangka panjang dampaknya mulai tidak signifikan meskipun masih bersifat positif. Temuan ini menunjukkan bahwa proses industrialisasi yang terjadi di Indonesia memiliki peranan yang penting bagi peningkatan ekspor, dan sekaligus mendukung hipotesis lqnacy tentang perkembangan struktur perekonomian.

5. Variabel penanaman modal asing (PMA) membawa dampak positif tetapi hanya memiliki signifikansi pada jangka panjang bagi perubahan volume ekspor. Hasil pengamatan ini sesuai dengan pengamatan Ali (1987).

6. Dari beberapa contoh kasus yang diestimasi dengan menggunakan model yang sama, terlihat adanya perbedaan hasil untuk setiap komoditas ekspor. Fakta ini menunjukkan bahwa setiap komoditas ekspor memiliki sifat yang unik, yang berbeda dengan komoditas lain.

Dari hasil estimasi dan problematika yang dihadapi dalam penelitian ini, peneliti ingin mengajukan saran yang dapat digunakan bagi para peneliti lain untuk bidang analisis yang sama, dan bagi para pengambil keputusan tentang perdagangan luar negeri di Indonesia, yaitu:

1. Perlunya melakukan modifikasi model estimasi yang memiliki perspektif jangka panjang dan jangka pendek dengan model estimasi yang mampu mengatasi problema ketidak sesuaian data dengan tuntutan asumsi linear klasik. Untuk itu perlu dipertimbangkan adanya model analisis Error Correction Model yang dioperasionalkan dengan metode Maximum Likelihood yang tidak menuntut asumsi yang ketat untuk data analisis. 
2. Di samping itu juga disarankan untuk secara lebih intensif mengamati perilaku komoditas ekspor sebagai sebuah kasus. Hal ini diperlukan mengingat dari hasil estimasi yang telah dilakukan tiap komoditas memiliki kecenderungan untuk bersifat unik. 


\section{DAFTAR PUSTAKA}

Ali, I. , 1987, "India's Manufactured Export: An Analysis of Supply Factors", The Developing Economics Journal, Juni 1987, XXV(2), hal.152-163.

Balassa, B., 1985, "Exports, Policy Choices, and Economic Growth in DevelopingCountries After the 1973 Oil Shock", Journal of Development Economics, 1985, 18, hal. 23-35.

Ballasa, B., 1988,

"Essay in Development Strategy", San Fransisco International Center for Economic Growth.

Working Paper. 1988.

Bond, M., E., 1985, "Export Demand and Supply for Group of Non Oil Developing Countries", IMF Staff Paper, vol. 32: 56-77, 1985.

Bond, M.E., 1987,

"An Econometric Study of Primary Commodity Exports from Developing Countries Region to the World", IMF Staff Paper, hal. 191-227, 1987

Chenery, H.B., 1978,

Structural Change and Development Policy, Oxford University Press, London.

Chenery, H.B. dan Keesing, D,B., 1979, "The Changing Composition of Developing Countries Exports", World Bank Staff Working Paper, No. 3/4, January 1979.

Chenery, H.B. dan M, Syrquin, 1975, Patern of Development 1950-1970, Oxford .University Press, London.

Dodaro, S., 1993, "Exports and Growth: A Reconsideration of Causality", The Journal of Developing Areas, 1993, 27, hal. 227-244.

Engle, R.F. dan C.W.J Granger, 1987, "Cointegration and Error Correction; Representation, Estimation, dan Testing", Econometrica, 1987, 55(2). Hal. 251-276.

Gemmell, N. 1994, IImu Ekonomi Pembangunan; Beberapa Survai, terjemahan, LP3ES, Jakarta. Goldstein, M. dan M.S. Khan., 1979,

"The Supply and Demand for Exports: A Simultaneous Approach", The Review of Economics and Statistics, 1979, 60, hal. 278-286.

Gujarati, D., 1995, Basic Econometrics, McGraw Hill Inc, New York.

Indrawati, S.M., 1996, "Sumber-Sumber Inflasi di Indonesia", Makalah Seminar ISEI Jaya 18 Januari 1996. 
Krugman dan Obstfeld. 1994, Ekonomi Internasional: Teori dan Kebijaksanaan terjemahan, Rajawali Pers, Jakarta.

Mukherjee, T.K. dan A. Naka., 1995, "Dynamic Relations Between Macroeconomic Variables and The Japanese Stock Market: An Application of A Vector Error Correction Model". The Journal of Financial Research, 1995, XVIII (2), hal. 223-237.

Muscatelli, V. A., T.G. Srinivasan, dan D. Vines., 1992, "Demand and Supply Factors in the Determinants of NIE Export: A Simultaneous Error-Correction Model for Hong Kong". The Economic Journal, 1992, 102, hal. 1467-1477.

Nafziger, E.W., 1997, The Economics of Developing Countries. Prentice-Hall, New Jersey.

Poot, H., A. Kuyvenhoven, dan J. Jansen, 1991, Industrialisation and Trade in Indonesia. Gadjah Mada University Press, Yogyakarta.

Ranis, G., 1988, Analytics of Development: Dualism, dalam (Chenery, H. and T.N. Srinivasan, eds.). Handbook of Development Economics. Elsevier Science Publishers.

Riedel, J., 1988, "The Demand for LCD Export of Manufactures: Estimates from Hong Kong". The Economic Journal, 1988, 98, hal. 138-148.

Stiglitz, J.E., 1988, Economic Prganization, Information, and Development, dalam (Chenery, H. and T.N. Srinivasan, eds.). Handbook of Development Economics. Elsevier Science Publishers. Syrquin, M., 1988, Patterns of Structural Change, dalam (Chenery, H. and T.N. Srinivasan, eds.). Handbook of Development Economics. Elsevier Science Publishers.

Wong, C.M., 1986, "Models of Export Instability and Empirical Test for Less-Developed Countries". Journal of Development Economics, 1986, 20, hal. 263-285. 